\title{
Media pembelajaran kearsipan elektronik berbasis website
}

\author{
Afrida Ghea Rizky, Imam Bukhori* \\ Universitas Negeri Malang, Jl. Semarang No. 5 Malang, Jawa Timur, Indonesia \\ *Penulis korespondensi, Surel: imbuchori@um.ac.id
}

Paper received: 3-5-2021; revised: 24-5-2021; accepted: 28-5-2021

\begin{abstract}
Abstrak
Kemajuan teknologi pada era globalisasi saat ini memiliki pengaruh terhadap dunia pendidikan, di dalam dunia pendidikan terdapat kegiatan belajar dan pembelajaran. Dalam kegiatan pembelajaran ini guru memberikan strategi-strategi untuk mewujudkan tercapainya hasil belajar yang memuaskan. Salah satu contohnya yaitu dengan adanya penggunaan media pembelajaran dalam proses pembelajaran. Tujuan adanya media pembelajaran yakni untuk mendorong belajar siswa agar dapat mengikuti proses pembelajaran sesuai dengan alurnya. Berkaitan dengan hal tersebut, dibutuhkan sebuah sistem yang dapat meningkatkan kualitas kegiatan pembelajaran sebagai penunjang proses pembelajaran. Media Pembelajaran Kearsipan Elektronik merupakan sebuah sistem kearsipan elektronik berbasis website yang membutuhkan jaringan internet untuk mengakses nya. Kegiatan pembelajaran kearsipan elektronik dapat dilakukan dimanapun dan kapanpun pengguna berada. Sistem tersebut tidak hanya menyediakan fasilitas untuk menginput arsip saja, namun dalam media pembelajaran tersebut juga terdapat materi dan soal sebagai proses evaluasi kegiatan pembelajaran kearsipan elektronik. Kemudahan dalam kegiatan pembelajaran secara jarak jauh dengan menggunakan media pembelajaran kearsipan elektronik berbasis website ini akan memiliki dampak yang positif bagi siswa dalam meningkatkan hasil belajarnya. Karena siswa dapat melakukan kegiatan pembelajaran kearsipan dengan begitu mudah, maka akan memotivasi siswa dalam meningkatkan hasil belajarnya. Hasil penelitian menyatakan bahwa media pembelajaran kearsipan elektronik berbasis website ini layak digunakan untuk kegiatan pembelajaran kearsipan elektronik. Dengan adanya media pembelajaran tersebut, siswa mudah dalam melakukan kegiatan pembelajaran kearsipan elektronik. Kemudahan dalam memperoleh materi dan media pembelajaran ini dapat memotivasi siswa untuk meningkatkan hasil belajarnya.
\end{abstract}

Kata kunci: penelitian dan pengembangan; media pembelajaran; website; kearsipan elektronik; hasil belajar siswa

\section{Pendahuluan}

Perkembangan teknologi sangat berpengaruh pada kehidupan sehari-hari. Salah satunya pada dunia pendidikan, perkembangan teknologi ini memberikan manfaat yang baik dan berpengaruh dalam kehidupan masyarakat (Ishak, dkk 2020). Selain itu dalam dunia pendidikan terdapat kegiatan belajar dan pembelajaran. Dalam kegiatan pembelajaran ini guru memberikan strategi-strategi untuk mewujudkan tercapainya hasil belajar yang memuaskan. Salah satu contohnya yaitu dengan adanya penggunaan media pembelajaran dalam proses pembelajaran. menurut Yaumi, (2018) menjelaskan bahwa terdapat hubungan signifikan antara penggunaan media dengan peningkatan hasil belajar. Jadi, suatu media sangat dibutuhkan untuk meningkatkan hasil pembelajaran pada suatu kegiatan pembelajaran. media pembelajaran ini dapat meningkatkan keinginan dan minat, meningkatkan motivasi dan rangsangan belajar, serta dapat membawa pengaruh psikologis terhadap siswa (Rusmayanti, 2015). Jadi dapat disimpulkan bahwa tujuan adanya media pembelajaran yakni untuk mendorong belajar siswa agar dapat mengikuti proses pembelajaran sesuai dengan alurnya.

Teknologi yang berkembang saat ini dan sedang beredar di kalangan masyarakat yakni adalah teknologi komputer. Dalam kegiatan sehari-hari komputer sudah banyak digunakan, 
namun pada kegiatan pembelajaran teknologi komputer ini masih minim penggunaannya. Menurut Anderson dalam Sutopo (2012) kemampuan komputer berinteraksi secara tepat dan aurat, cepat dan tepat, serta dapat menyimpan data dalam jumlah yang besar dan aman. Jadi komputer sudah menjadi media yang cocok dan dominan dalam bidang pendidikan di banding dengan media yang lain. Dalam kegiatan pembelajaran online ini dapat dilakukan dengan berbagai cara, namun akan lebih baik jika peseta didik diberikan fasilitas media pembelajaran yang dapat diakses dengan mudah oleh siswa dalam melakukan kegiatan pembelajaran online. Media pembelajaran memberikan kemudahan peserta didik dalam menerima materi yang disampaikan oleh guru, baik materi pengetahuan maupun materi praktik pembelajaran. media pembelajaran juga dapat membantu peserta didik melakukan self study dalam mewujudkan visi pendidikan global yang telah dijelaskan oleh Rapidble dalam Yaumi (2018).

Program keahlian yang terdapat di Sekolah Menengah Kejuruan begitu banyak salah satunya yakni program Keahlian Otomatisasi Tata Kelola Perkantoran dengan terdapat konsentrasi pada bidang perkantoran, pekerjaan yang dilakukan dalam perkantoran. Dalam kegiatan pembelajaran nya terdapat mata pelajaran kearsipan. Mata pelajaran kearsipan merupakan mata pelajaran yang mengajarkan ilmu kearsipan dimulai dari menyimpan arsip hingga pemusnahan arsip. Menurut Sugiarto \& Wahyono (2015) kearsipan merupakan bentuk pekerjaan tata usaha yang berupa penyusunan warkat-warkat secara sistematis sehingga apabila dibutuhkan lagi, warkat-warkat tersebut dapat ditemukan dengan mudah dan cepat. Sugiarto \& Wahyono (2015) menyatakan bahwa arsip merupakan data yang akan digunakan sebagai pengambilan suatu keputusan, maka dari itu arsip harus dengan mudah dan cepat. Dalam pelaksanaannya jika suatu pekerjaan ingin dijalankan secara cepat maka harus menggunakan teknologi informasi atau sistem informasi. Dari pernyataan tersebut maka dalam pelaksanaan pembelajaran kearsipan membutuhkan media pembelajaran yang dapat digunakan sebagai media mempraktikkan materi yang sudah diberikan oleh guru.

Seperti penelitian yang dilakukan oleh Putria (2018) mengenai media pembelajaran yang berbasis website menunjukkan bahwa penelitiannya berupa Sistem kearsipan berbasis website ini telah berhasil dalam mengelola data siswa secara efektif dan efisien. Karena sistem ini dapat dijalankan secara online maka siswa dapat mengakses sistem tersebut dimanapun dan kapanpun dengan mudah. Begitu juga dengan hasil penelitian dari Castro, dkk (2016) mengenai program kearsipan elektronik menyatakan bahwa sistem tersebut dapat berjalan secara efektif dan mudah digunakan oleh penggunanya.

Mata pelajaran kearsipan merupakan salah satu mata pelajaran dalam kelompok C2 yakni mata pelajaran dasar kompetensi program keahlian Otomatisasi Tata Kelola Perkantoran yang seharusnya dapat terlaksana dengan semaksimal mungkin serta menjadi salah satu kompetensi bagi peserta didik sebagai bekal setelah lulus dari kemampuan kognitif dan psikomotorik peserta didik. Maka dri itu mata pelajaran ini penting untuk dijalankan secara maksimal dengan penggunaan media pembelajaran yang dapat mendukung peserta didik untuk merasakan pengalaman praktik Kearsipan Elektronik. Dengan penggunaan media pembelajaran yang tepat dengan kompetensi dasar maka akan menumbuhkan minat belajar peserta didik dengan sungguh-sungguh untuk meningkatkan pemahaman materi yang diberikan oleh guru. Berdasarkan latar belakang tersebut, maka peneliti memilih judul Pengembangan media kearsipan elektronik berbasis website. 


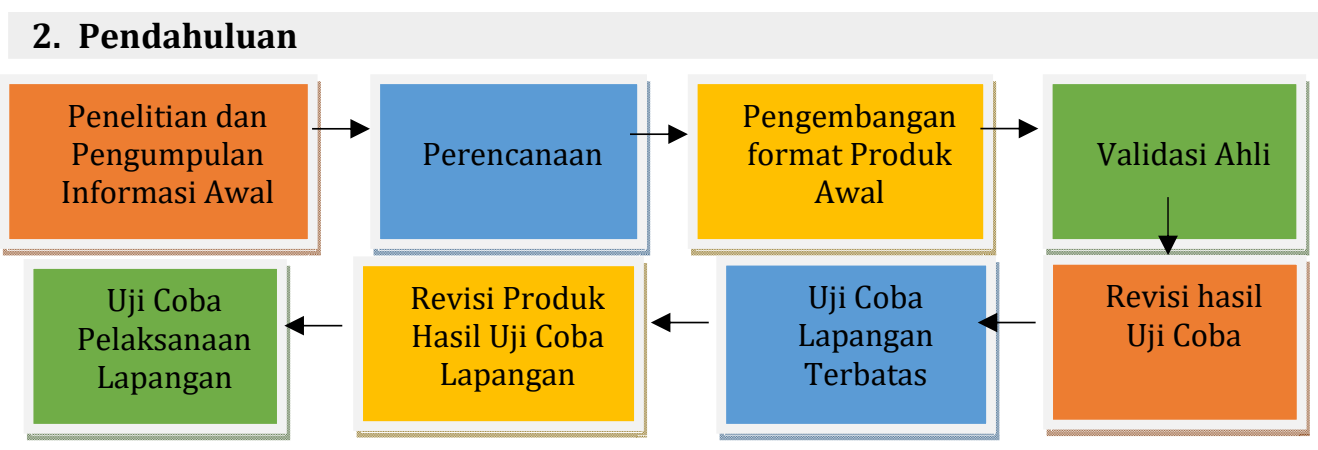

Gambar 1. Langkah-langkah penggunaan Metode Research dan Development (R\&D)

Penelitian ini menggunakan model Research and Development Borg and Gall menurut (Sugiyono, 2011) yang telah dimodifikasi menjadi delapan tahapan untuk mempersingkat waktu dan meminimalisir biaya. Selain itu, peneliti juga merasa bahwa tujuan penelitian adalah untuk menghasilkan suatu produk, mengetahui kelayakan produk serta mengetahui perbedaan hasil belajar siswa dalam menggunakan media pembelajaran kearsipan elektronik dengan yang tidak menggunakan media pembelajaran kearsipan elektronik berbasis website (Mugas-Arsip).

Langkah pertama, peneliti mengumpulkan informasi terkait dengan permasalahan yang terdapat di SMK Muhammadiyah 3 Singosari Malang yakni kurangnya media pembelajaran kearsipan elektronik sebagai penunjang kegiatan pembelajaran kearsipan elektronik pada kelas XI OTKP. Langkah kedua yakni peneliti melakukan perancangan produk media pembelajaran yang akan dikembangkan serta dapat menjadi solusi dari permasalahan yang terdapat di SMK Muhammadiyah 3 Singosari Malang. Berikutnya peneliti melakukan pengembangan format produk awal berupa media pembelajaran kearsipan elektronik yang dapat dijalankan secara online sehingga dapat memudahkan penggunanya mengakses media tersebut. Setelah produk awal dibuat, langkah selanjutnya peneliti melakukan Validasi terhadap ahli materi dan ahli media sebagai bahan perbaikan produk. Setelah melakukan validasi terhadap ahli, peneliti melakukan tahapan revisi produk dari saran serta masukan dari para ahli, baik itu dari ahli materi maupun ahli media. perbaikan hasil validasi ahli ini bertujuan untuk mengetahui apakah media pembelajaran kearsipan elektronik tersebut layak untuk diujicobakan kepada pengguna.

Langkah selanjutnya setelah peneliti melakukan perbaikan terhadap produk yang dikembangkan yakni melakukan uji coba lapangan terbatas yang dilakukan oleh 6 siswa XI OTKP 1. Setelah melakukan uji coba terhadap siswa, peneliti melakukan tahapan revisi sebelum produk diujicobakan kepada seluruh siswa. Selanjutnya, peneliti melakukan uji coba kelompok besar kepada seluruh siswa kelas XI OTKP 1 sebagai kelas eksperimen dan XI OTKP 2 sebagai kelas kontrol yang dalam kegiatan pembelajaran nya tidak menggunakan media kearsipan elektronik pada penelitian ini.

Data yang dihasilkan oleh peneliti berupa data kualitatif dan data kuantitatif, dimana data kualitatif didapatkan dari kritik dan saran dari para ahli materi dan ahli media. Sedangkan data kuantitatif diperoleh dari hasil angket. 


\section{Hasil dan Pembahasan}

\subsection{Sistem Informasi Akademik}

Media merupakan seluruh bentuk dan penyampaian yang dipergunakan setiap orang dalam menyampaikan pesan atau informasi AECT dalam Sadiman, (2010). Menurut Djamarah (2010) media merupakan wadah penyalur informasi belajar yang berisikan pesan. Sedangkan menurut Rossi \& Breudke dalam Sanjaya (2012) media pembelajaran merupakan alat dan bahan yang dapat digunakan dalam mencapai tujuan pendidikan seperti radio, televisi, koran, buku, majalah, dan sebagainya. seluruh benda maupun komponen yang terdapat di sekitar siswa dengan memiliki fungsi untuk dapat merangsang pola pikir siswa juga dapat dinyatakan sebagai media pembelajaran. Dengan demikian suatu media pembelajaran terbentuk karena terdapat peralatan yang dapat digunakan serta pesan atau informasi yang akan disampaikan melalui media sebagai perantaranya.

Penggunaan media dalam kegiatan belajar mengajar dapat meningkatkan minat, motivasi, rangsangan serta pengaruh psikologis terhadap siswa (Hamalik dalam Tatang, 2015:55). Sedangkan menurut Sanjaya (2012) mengemukakan bahwa penggunaan media harus dapat mempermudah siswa dalam memahami materi pembelajaran. dari pendapat beberapa ahli tersebut dapat disimpulkan bahwa media pembelajaran merupakan segala sesuatu yang digunakan sebagai perantara dalam menyampaikan pesan atau informasi antara guru dan siswa selama kegiatan belajar mengajar. Dalam mewujudkan tujuan pembelajaran harus membuat media pembelajaran yang kreatif seperti halnya menggabungkan beberapa media audio, media visual serta media audio visual.

\subsubsection{Jenis-Jenis Media Pembelajaran}

Menurut Sanjaya (2012) mengklasifikasikan media menjadi beberapa macam tergantung sudut pandangnya yaitu:

\subsubsection{Dilihat dari Sifatnya}

(a) Media auditif, yakni media yang hanya dapat didengar saja. (b) Media visual, yaitu media yang dapat dilihat saja. (c) Media audiovisual, yaitu media yang mengandung unsur suara untuk didengar serta mengandung unsur gambar yang bisa dilihat.

\subsubsection{Dilihat dari Kemampuan Jangkauannya}

(a) Media yang mempunyai daya tangkap yang luas dan serentak seperti radio dan televisi. (b) Media yang mempunyai daya tangkap yang terbatas oleh ruang dan waktu seperti film slid, video, film, dsb.

\subsubsection{Dilihat dari Cara atau Teknik Pemakaiannya}

(a) Media yang dapat diproyeksikan tanpa bantuan alat lainnya maka media tersebut tidak dapat berjalan secara optimal. (b) Media yang tidak diproyeksikan seperti foto, gambar, lukisan, dsb. 


\subsubsection{Fungsi Media Pembelajaran}

Menurut Gerlach \& Ely dalam Tatang (2015) kelebihan dari media diantaranya kemampuan fiksatif, kemampuan manipulatif dan kemampuan distributif. Berikut penjelasan dari kelebihan media pembelajaran.

(a) Kemampuan fiksatif merupakan kemampuan menangkap, menyimpan, dan menampilkan kembali suatu objek atau peristiwa. (b) Kemampuan manipulatif merupakan media yang dapat menampilkan kembali objek atau peristiwa dengan berbagai macam perubahan (manipulasi) sesuai dengan kebutuhan. (c) Kemampuan distributif yaitu kemampuan dimana jangkauan media dengan audience berjumlah besar dalam satu kali penarikan secara serentak, misalnya seperti siaran televisi dan radio.

\subsection{Arsip Elektronik}

Arsip elektronik adalah sebuah informasi yang direkam dan tersimpan di dalam media elektronik berbentuk digital. National Archive and Record Administration (NARA) USA dalam Sugiarto \& Wahyono (2015) menyatakan bahwa arsip elektronik merupakan dokumen yang disimpan dan diolah di dalam suatu format, dan hanya komputer yang dapat memproses nya. Pendapat lain dari Wallace dalam Sugiarto \& Wahyono (2015) yang menyatakan bahwa arsip elektronik merupakan bagian dari informasi yang sudah terekam dalam sebuah kode yang dapat ditemukan kembali, digunakan dan dibaca oleh penggunanya.

Berikut merupakan kegiatan dari penanganan arsip elektronik yaitu mengenai surat menyurat. Dimana kegiatan surat menyurat ini dibagi menjadi dua, yakni sebagai berikut:

\subsubsection{Penanganan Surat Masuk}

Surat masuk adalah surat yang diterima oleh suatu instansi/organisasi yang berasal dari perorangan ataupun instansi organisasi lain yang mengandung informasi sesuai dengan kepentingan organisasi tersebut. Menurut Herawati \& Riana (2017) terdapat 3 sistem yang dapat digunakan dalam pengelolaan surat masuk yaitu Sistem Buku Agenda, Sistem Kartu Kendali Sistem Takah (Tata naskah).Adapun pengelola surat masuk menggunakan sistem buku agenda menurut Herawati \& Riana (2017:67-72) adalah sebagai berikut:

(a) Penerimaan surat, dalam kegiatan ini dapat dilakukan oleh petugas yang bekerja di bagian depan atau front office. (b) Penyortiran surat, yaitu untuk memilah surat berdasarkan jenis surat. Apabila surat yang diterima adalah surat pribadi, maka dapat segera diberikan pada nama pribadi yang dituju. (c) Pencatatan surat, kegiatan untuk mencatat surat masuk menggunakan agenda sesuai dengan jenis agenda yang digunakan. (d) Pengarahan surat, kegiatan ini merupakan pengarahan berupa instruksi yang diberikan oleh pimpinan, instruksi mengenai tindak lanjut surat tersebut dapat dituliskan dalam lembar disposisi. (e) Penyampaian surat, apabila pimpinan telah memberikan instruksi yang ditulis dalam lembar disposisi maka surat dapat diberikan kepada pihak yang bersangkutan sesuai dengan perintah pimpinan. (f) Penyimpanan surat, setelah surat melalui beberapa pengelolaan dari tahap ke tahap maka surat asli harus diberikan kepada unik penyimpanan arsip berdasarkan sistem kearsipan yang telah diberikan. 


\subsubsection{Penanganan Surat Keluar}

Sistem penanganan surat adalah prosedur-prosedur yang digunakan untuk menangani surat keluar. Dalam penelitian dan pengembalian ini sistem yang digunakan adalah sistem buku agenda yang sudah terkomputerisasi kan dan dilengkapi dengan format surat keluar. Surat keluar juga butuh pengelolaan yang tepat agar tujuan dikeluarkannya surat tersebut dapat mencapai tujuan yang diharapkan, sama halnya dengan surat masuk, dalam surat keluar terdapat 3 sistem pengelolaan yaitu sistem buku agenda, sistem kartu kendali dan sistem takah (tata naskah). Adapun prosedur dalam pengelolaan surat keluar menggunakan sistem buku agenda menurut Herawati \& Riana (2017:79-81) adalah sebagai berikut:

(a) Menurut konsep surat keluar. (b) Memberikan persetujuan pada konsep surat. (c) Mencatat surat (d) Mengetik konsep surat keluar. (e) Memeriksa hasil pengetikan konsep surat. (f) Menandatangani surat. (g) Membubuhkan cap dinas. (h) Melipat surat. (i) Memasukan surat ke dalam sampul surat harus disertai dengan nomor surat dan kop surat dan kop instansi. (j) Mengirim surat, surat dapat dikirim melalui jasa pengiriman berupa kurir, pos ataupun e-mail.

\subsection{Website}

\subsubsection{Pengertian Website}

Menurut buku dari Mulanto (2010) Website merupakan sebuah laman yang berisikan tentang informasi yang dapat dilihat jika pengguna memiliki komputer yang terkoneksi dengan internet. Dengan keberadaan Website ini menjadikan semua orang di dunia dapat memperoleh dan mengelola informasi melalui berbagai sumber yang tersedia di internet.

Sedangkan menurut Hidayat (2010) website adalah suatu kumpulan halaman web yang memuat data dan informasi yang disajikan dalam berbagai bentuk baik bersifat dinamis maupun statis yang membangun rangkaian halaman web yang saling berkaitan dan dihubungkan dengan hyperlink.

\subsubsection{Jenis-jenis Website}

Berdasarkan pengoperasian nya, secara mendasar website dibedakan menjadi dua jenis, yaitu website static dan website dynamic Hidayat (2010).

\subsubsection{Website Statis}

Website statis merupakan website yang mempunyai halaman front end, yaitu halaman yang dapat dilihat oleh pengunjung website. Dikarenakan fasilitas sangat terbatas, menjadikan isi dari halaman bersifat tetap dan tidak berubah. Jika ingin mengganti halaman web statis harus melakukan perubahan secara manual dan harus mengganti semua kode-kode HTML yang merupakan unsur utama pembuatan website.

\subsubsection{Website Dinamis}

Website dinamis merupakan website yang dapat diubah maupun di-update. Dalam website dinamis terdapat dua halaman yaitu halaman front end dan back end. Pada halaman front end adalah halaman yang dapat diakses semua user, sedangkan halaman back end 
merupakan halaman yang hanya dapat diakses oleh admin maupun yang bersangkutan. Fungsi dari back end sendiri yaitu untuk mengatur front end. Sebagai contoh sebagai pengaturan isi artikel, pengaturan tampilan front serta tambahan untuk menghias front end.

\subsubsection{Fungsi Website}

Menurut Helianthusonfri (2013:8) yang berjudul Website Gratis dan Praktis, Hasil Fantastis mengungkapkan bahwa website memiliki beberapa fungsi, yaitu:

(a) Sebagai media untuk mempublikasikan informasi. (b) Sebagai media promosi. (c) Sebagai pembentukan komunitas. (d) Sebagai media dalam kegiatan jual beli Online. (e) Sebagai peningkatan profesionalitas dalam menguasai IPTEK

\subsection{Mata Pelajaran Kearsipan}

Mata pelajaran kearsipan adalah salah satu mata pelajaran yang masuk dalam golongan C2 yakni mata pelajaran dasar kompetensi dari jurusan program keahlian Otomatisasi Tata Kelola Perkantoran. Mata pelajaran kearsipan merupakan mata pelajaran yang mengajarkan bagaimana cara mengelola arsip. Mulai dari konsep arsip, jenis-jenis arsip, sistem penyimpanan, alat penyimpanan, menambah arsip hingga melakukan pemusnahan arsip.

\subsection{Mugas-Arsip}

Mugas Arsip merupakan media pembelajaran kearsipan elektronik yang dapat diakses oleh penggunanya dengan mudah. Media pembelajaran ini dijalankan secara Online sehingga pengguna diharapkan untuk menghubungkan aplikasi dengan koneksi internet. Media pembelajaran kearsipan ini tidak hanya sebagai media untuk melakukan praktik kearsipan secara elektronik, namun siswa dapat melihat materi, panduan penggunaan hingga mengerjakan soal yang terdapat dalam aplikasi tersebut sebagai bahan evaluasi kegiatan pembelajaran kearsipan elektronik.

\section{Simpulan}

Penelitian dan pengembangan ini menghasilkan sebuah media pembelajaran kearsipan elektronik berbasis website untuk meningkatkan hasil belajar siswa pada mata pelajaran kearsipan elektronik kelas XI OTKP di SMK Muhammadiyah 3 Singosari Malang. Media pembelajaran ini bernama Kearsipan elektronik yang dapat di akses dengan mudah melalui browser.

Media pembelajaran kearsipan elektronik pada penelitian ini dinyatakan "Sangat Valid" dan layak untuk digunakan dalam kegiatan pembelajaran kearsipan elektronik melalui validasi ahli materi, ahli media, serta uji coba kelompok kecil. Selain itu, media pembelajaran kearsipan elektronik berbasis website ini terbukti efektif dalam meningkatkan hasil belajar siswa pada uji coba kelompok besar. Media kearsipan elektronik ini juga memungkinkan pembelajaran dimanapun dan kapanpun pengguna berada. Bahkan siswa dapat secara mandiri tanpa harus terikat dengan kegiatan tatap muka di sekolah, sehingga media kearsipan elektronik ini dapat berguna dilakukan dalam kondisi pandemic covid-19 ini. 
Media pembelajaran kearsipan elektronik berbasis website ini hanya berfokus pada materi kearsipan elektronik dan terbatas pada sistem website, sehingga diharapkan peneliti selanjutnya dapat menyajikan proses penginputan surat dengan cara lain.

\section{Ucapan Terima Kasih}

Peneliti mengucapkan terima kasih kepada Universitas Negeri Malang yang telah memfasilitasi dan memungkinkan peneliti untuk melakukan penelitian dan pengembangan ini.

\section{Daftar Rujukan}

Akbar. (2017). Instrumen Perangkat Pembelajaran. PT Remaja Rosdakarya.

Castro, R., Abadie, L., Makushok, Y., Makijarvi, P., Vega, J., Ruiz, M., Sanz, D., Simrock, S., Faig, J., \& Roman-Perez, G. (2016). Data archiving system implementation in ITER's CODAC CORE SYSTEM. Proceedings Symposium on Fusion Engineering, 2016-May, 3-6. https://doi.org/10.1109/SOFE.2015.7482290

Djamarah, Z. (2010). Strategi Belajar Mengajar. Rineka Cipta.

Foladi, S., Hedayati, M. T., Shokohi, T., \& Mayahi, S. (2013). Study on fungi in archives of offices, with a particular focus on Stachybotrys chartarum. Journal de Mycologie Medicale, 23(4), 242-246. https://doi.org/10.1016/j.mycmed.2013.09.003

Helianthusonfri, J. (2013). Website Gratis dan Praktis, Hasil Fantastis. PT Elex Komputindo Kompas, Gramedia.

Herawati, I., \& Riana, S. (2017). Bahan Ajar Administrasi Umum SMK Bidang Keahlian Bisnis dan Manajemen Kelas X Semester Gasal (B. D. \& Pemasaran (ed.)).

Hidayat, R. (2010). Cara Praktis Membangun Website Gratis : Pengertian Website. PT Elex Komputindo Kompas, Gramedia.

Ishak, R., Akbar, F., \& Safudin, M. (2020). Rancang Bangun Sistem Informasi Surat Masuk Dan Surat Keluar Berbasis WEB Menggunakan Metode Waterfall. Jurnal Indonesia Sosial Teknologi, 1(3), 198-209.

Kuswantoro, A., \& Ashari, T. N. (2018). Pengembangan Aplikasi Elektronik Arsip (E Arsip) Pembelajaran Jurusan Administrasi Perkantoran. Lentera Pustaka: Jurnal Kajian Ilmu Perpustakaan, Informasi Dan Kearsipan, 4(1), 17. https://doi.org/10.14710/lenpust.v4i1.20021

Mulanto, S. (2010). Membangun Website Tanpa Modal (H. P (ed.); 1st ed.). ANDI.

Nugraha, J. A., Widiyanto, A., \& Primadewi, A. (2018). Sistem Pengelolaan Arsip Dengan Menerapkan Manajemen Akses User Berbasis Web Pada Yppalb B (Tunarungu Wicara) Kota Magelang. Jurnal Komtika, 2(1), 49-54. https://doi.org/10.31603/komtika.v2i1.2112

Palisoa, A. N. S., \& Manuhutu, M. A. (2020). E-Archive Development In PT Haleyora Powerindo Sorong. IJISTECH (International Journal of Information System \& Technology), 4(1), 409-416.

Oliver, G., Chawner, B., \& Liu, H. P. (2011). Implementing digital archives: Issues of trust. Archival Science, 11(34), 311-327. https://doi.org/10.1007/s10502-011-9167-9

Purwanto, \& Ramadhan, A. N. (2016). Pengembangan software kearsipan elektronik berbasis web sebagai bahan ajar mata kuliah simulasi perkantoran. Penguatan Hubungan Antara Pengembangan Keterampilan, Pendidikan Dan Ketenagakerjaan Generasi Muda, 155-180. http://eprints.uny.ac.id/41248/1/14 Purwanto.pdf.

Putria, A. (2018). Media Pembelajaran Inovatif dan Pengembangannya. Remaja Rosdakarya.

Rusmayanti, A. (2015). Sistem Informasi Pengelolaan Keuangan Pada Desa Ngadirejan. Speed - Sentra $\begin{array}{llll}\text { Penelitian Engineering Dan } & \text { Edukasi, } & \text { 35-39. }\end{array}$ http://www.ijns.org/journal/index.php/speed/article/view/1321/1309

Sadiman, A. (2010). Media Pendidikan Pengertian Pengembangan dan Pemanfaatannya. Rajawali Pers.

Saeroji, A. (2014). INOVASI MEDIA PEMBELAJARAN KEARSIPAN ELEKTRONIK ARSIP (E-ARSIP) BERBASIS MICROSOFT OFFICE ACCESS. Dinamika Pendidikan Unnes, 9(2), 177-185. https://doi.org/10.15294/dp.v9i2.4893

Sanjaya, W. (2012). Strategi Pembelajaran Berorientasi Standar Pendidikan. Kencana.

Saryani, S., Harfizar, H., \& Arianto, R. (2019). Rancangan Sistem Informasi E - Arsip Surat Masuk dan Surat Keluar. TMJ (Technomedia Journal) Vol. 4 No. 1 Agustus 2019, 69. 
Jurnal Ekonomi, Bisnis dan Pendidikan, 1(5), 2021, 479-487

Siahaan, Y. L. O., \& Meilani, R. I. (2019). Sistem Kompensasi dan Kepuasan Kerja Guru Tidak Tetap di Sebuah SMK Swasta di Indonesia. Jurnal Pendidikan Manajemen Perkantoran, 4(2), 141. https://doi.org/10.17509/jpm.v4i2.18008

Suganda, D. (2015). Pengembangan Media Kearsipan dengan Menggunakan Aplikasi Pengolahan Data Arsip Untuk siswa Kelas XII Program Studi Administrasi Perkantoran. Jurnal Pendidikan Bisnis Dan Manajemen, 1(1), 1689-1699.

Sugiarto, A., \& Wahyono, T. (2015). Manajemen Kearsipan Elektronik. Penerbit Gava Media.

Sugiyono. (2011). Metode Penelitian Pendidikan Pendekatan Kuantitatif, Kualitatif, dan R\&D (A. CV (ed.)).

Suryadi, A. (2019). Rancang Bangun Sistem Pengelolaan Arsip Surat Berbasis Web Menggunakan Metode Waterfall (Studi Kasus : Kantor Desa Karangrau Banyumas). Jurnal Khatulistiwa Informatika, 7(1), 1321. https://doi.org/10.31294/jki.v7i1.36

Sutopo, A. H. (2012). Teknologi Informasi dan Komunikasi Dalam Pendidikan. Graha Ilmu.

Syahputra, H. (2017). PEMBANGUNAN SISTEM INFORMASI KEARSIPAN BERBASIS WEB DI SEKOLAH MENENGAH KEJURUAN NEGERI 6 PADANG DENGAN MENGGUNAKAN PHP DAN. 4(2), 234-240.

Tatang, A. (2015). Manajemen Pendidikan. UNY Press.

Wirawan, A. W., Indrawati, C. D. S., \& Rahmanto, A. N. (2017). Pengembangan media pembelajaran kearsipan digital untuk meningkatkan hasil belajar siswa SMK Negeri 3 Surakarta. Jurnal Pendidikan Vokasi, 7(1), 78. https://doi.org/10.21831/jpv.v7i1.12879

Yaumi, M. (2018). Media Dan Teknologi Pembelajaran. Prenadamedia Group. 